\title{
Comparação do desempenho de frangos positivos e negativos para a presença de anticorpos contra o vírus da anemia das galinhas*
}

\author{
LAURICIO LIBRELOTTO RUBIN \\ Claudio Wageck Canal (Orientador - UFRGS) \\ Andréa M. L. Ribeiro (Co-orientadora - UFRGS)
}

Banca: Carlos Tadeu Pippi Salle (UFRGS), Clarice Weis Arns (UNICAMP), Liana Brentano (EMBRAPA/CNPSA)

O vírus da anemia das galinhas - CAV (chicken anemia virus) causa uma doença, em aves jovens, caracteriza por anemia, retardo no crescimento, mortalidade variável (2 a 20\%) e imunodepressão. O controle dessa doença é baseado na transferência de imunidade passiva das matrizes à progênie. Este trabalho teve como objetivo comparar o desempenho entre frangos nascidos positivos e negativos para a presença de anticorpos contra o CAV. Para isso, foram utilizados dois lotes de matrizes pesadas, sendo um vacinado e o outro não. Com a progênie obtida dessas matrizes de ambos os lotes, foram constituídos três tratamentos: T1 - pintos oriundos de matrizes vacinadas com títulos altos; T2 - pintos oriundos de matrizes não vacinadas com títulos médios e; T3 - pintos oriundos de matrizes não vacinadas com títulos baixos. Cada tratamento com 50 fêmeas e 50 machos. Todos os tratamentos permaneceram em regime de criação intensiva usual por 47 dias em 5 propriedades diferentes, portanto o experimento teve 5 repetições. Os dados analisados foram o peso inicial e final, conversão alimentar e mortalidade. Como resultado, foi observado que: 1- os frangos machos negativos (T3) foram mais pesados que os frangos machos positivos (T1 e T2). 2- já nas fêmeas, não houve diferença no peso final entre os tratamentos. 3- não houve diferença significativa entre os tratamentos em relação à mortalidade e a conversão alimentar. 4- não houve indício de desafio de campo. 5- a vacinação das matrizes contra o CAV não gerou melhora de títulos de anticorpos. 6- a vacinação de matrizes pesadas contra o CAV não gerou benefícios sobre a produtividade dos frangos de corte, nas condições testadas.

Descritores: vírus da anemia das galinhas, desempenho, frangos de corte, vacina, anticorpo.

\footnotetext{
* Dissertação de Mestrado n. 363 (Especialidade: Sanidade Avícola). 42 f. Programa de Pós-graduação em Ciências Veterinárias da Faculdade de Veterinária- UFRGS. CORRESPONDÊNCIA: L.L. Rubin [lauricio.rubin@ bol.com.br].
} 


\title{
Performance comparison between broilers positive and negative for antibodies against the chicken anemia virus**
}

\author{
LAURICIO LIBRELOTTO RUBIN
}

Claudio Wageck Canal (Adviser - UFRGS)

Andréa M. L. Ribeiro (Co-Adviser - UFRGS)

Committee: Carlos Tadeu Pippi Salle (UFRGS), Clarice Weis Arns (UNICAMP), Liana Brentano (EMBRAPA/CNPSA)

Chicken anemia virus (CAV) causes a disease among young birds characterized by anemia, growth retard, variable mortality (2 to 20) and immunodepression. The control of the infectious anemia in broilers lays on the transference of passive immunity to progeny by breeders. The objective of this study was to compare the performance between broilers born positive and negative to the presence of antibodies against the CAV. Two flocks of heavy breeders with similar ages were used. Breeders from one of the flocks were vaccinated while the breeders from the other were not. With the progeny obtained from breeders of both flocks, three treatments were constituted: T1 - chicks from vaccinated breeders with protecting titers; T2 - chicks from non-vaccinated breeders with average titers and; T3 - chicks from non-vaccinated breeders with low titer. Each treatment with 50 females and 50 males. In all treatments, intensive raising conditions were maintained for 47 days in 5 different properties; therefore, the experiment has been repeated 5 times. Data analyzed were initial and final weight, feeding conversion and mortality. It was observed that: 1- negative male broilers (T3) were heavier that positive broilers (T1 and T2). 2 - in the females there was no significant difference $(\mathrm{p}>0,05)$ between the treatments final weight. 3- there was no significant difference $(p>0.05)$ among the treatments in relation to mortality and feeding conversion. 4- serum analysis showed that CAV did not challenged poultry during the experimental period. 5-vaccination of breeders against CAV did not develop higher titers of antibodies. 6- vaccination of breeders against CAV did not generate progeny with better performance within the raising conditions tested.

Key words: chicken anemia virus, performance, broiler, vaccine, antibody. 